\title{
Management of Brazilian pine (Araucaria angustifolia (Bertol) Kuntze) based on the Liocourt model in a mixed ombrophilous forest in Southern Brazil
}

\author{
Ana Claudia da Silveira ${ }^{1}$, André Felipe Hess ${ }^{1}$, Luis Paulo Baldissera Schorr ${ }^{1 *}$, Sandra Mara Krefta ${ }^{1}$, Diego \\ Vinchiguerra dos Santos ${ }^{1}$, Mushue Dayan Hampel Vieira Filho ${ }^{1}$, Kemely Atanazio Alves Atanazio ${ }^{1}$, \\ Emanuel Arnoni Costa ${ }^{2}$, Thiago Floriani Stepka ${ }^{1}$, Geedre Adriano Borsoi ${ }^{1}$
}

\author{
${ }^{1}$ Department of Forest Engineering, Santa Catarina State University, 2090 Luiz de Camões Avenue, Lages, Santa \\ Catarina State, Brazil. Postal Code: 88520-000. \\ ${ }^{2}$ Department of Forest Engineering, Federal University of Santa Maria, 1000 Roraima Avenue, Santa Maria, Rio \\ Grande do Sul State, Brazil, Postal Code: 97105-900.
}

\section{*Corresponding author: luispaulo_schorr@hotmail.com}

\begin{abstract}
The sustainable management of mixed ombrophilous forest is an effective way to perpetuate the survival of Brazilian pine and to generate environmental, economic and social benefits. So, this study aimed to describe the dynamics of the diametric distribution to propose a management intervention using the Liocourt model for a natural forest of Araucaria angustifolia within 84 ha of forests located in Lages, SC, Brazil. A total of 25 permanent plots of $400 \mathrm{~m}^{2}$ were evaluated in two periods (periodic inventory performed in 2012 and 2016). The diameters at the breast height and the total height of all Brazilian pine individuals with diameter from 10 centimeters were measured. For the calculation of the quotient " $q$ " the individuals were divided into diametric classes with intervals of $5 \mathrm{~cm}$. The cutting intensity and the cutting rate for the cutting cycles of 20, 25 and 30 years were also calculated. This Brazilian pine forest presented J-inverted distribution curve and the value for the quotient " $q$ " was 1.32. The cutting rates were $44.89 \mathrm{~m}^{3}$. ha ${ }^{-1}, 63.64 \mathrm{~m}^{3}$. ha ${ }^{-1}$ and $86.52 \mathrm{~m}^{3}$. ha ${ }^{-1}$ for the cutting cycles of 20,25 and 30 years, respectively. In conclusion, this work demonstrated a forest structure that allows the forest management activity and the use of Liocourt method as a tool to elaborate forest management plans and to improve the forest interventions in Brazilian pine forests.
\end{abstract}

Keywords: forest dynamics, forest management, diameter distribution, Parana pine, forest measurement, silvicultural interventions.

Abbreviations: DBH_diameter at the breast height; "q"_Liocourt quotient value; PAIV_periodic annual increment in volume; NR_number of trees to be removed.

Introduction

Araucaria angustifolia (Bertol.) Kuntze. known as Brazilian Pine or Paraná Pine is a characteristic and exclusive native species of the Mixed Ombrophilous Forest (Lorenzi, 2002; Carvalho, 2003). The high-quality wood with wide applicability (Paula and Alves, 2007) combined with the high commercial value of its wood, have made this species subject to an intense process of predatory exploitation, which resulted in a drastic reduction of numbers (Medeiros et al, 2005).

Currently, the remainder of these forests is estimated about 2 to $4 \%$ of the original coverage area (Guerra et al., 2002). In view of that, some laws that prohibited the cutting of $A$. angustifolia were created to control the fragmentation of Brazilian pine forest but this prohibition was not efficient and it did not help to preserve the remnants of these forests.

An effective measure against the advance fragmentation of the mixed ombrophilous forest might be the forest management according to Rosot, (2007). Sanquetta (2003) emphasized that forest management is a decisive element to perpetuate the survival of Brazilian pine. It can contribute to stimulate the natural regeneration to increase the growth rates of the remaining trees and to reduce the natural mortality rates in the forest.

In order to achieve a quality management, we should obtain more knowledge about the structural dynamics of the forest and about the best forest management tools to perform the silvicultural interventions. Some studies have been developed with the aim of achieving the sustainable management of mixed ombrophilous forest using the Liocourt model (Hess et al., 2010, Hess, 2012; Hess et al., 2014). These projects have the purpose of regulating the number of individuals in overstocked environments, controlling the competition between trees, and consequently, maximizing the trees increment and production, characterizing a sustainable forest production. The Liocourt model was created to obtain the normal growing stock in a forest, to conserve and consequently ensuring a sustainable return (De Liocourt, 1898). This 
author emphasized that the forest is established by trees belonging to all diameter classes and he recommended the study of the diameters distribution. In what that could be considered an ideal forest conditions, the number of trees tends to decrease in successive diameter classes by a constant ratio, named $q$, the "diminution quotient" (Pageo and Arrarás, 2013).

The verification of the diameter distribution is fundamental because it allows the analysis of uneven-aged forests, enabling the foresters to know and understand the species that make the forest structure. It also allows a better planning to perform appropriate strategies to manage and conserve these environments (Batista et al., 2015).

It is important to emphasize that the Liocourt's method mainly describes the diameter distribution of natural forest, also indicates the demographic balance between in-growth, up-growth transitions of classes and mortality. It makes the Liocourt's method an important tool to promote management systems, once a management system planned by diameter distribution, where the harvest process can be considered sustainable (Picard and Gasparotto, 2016).

The study by Kerr (2014), reviewing the Liocourt's highlights the key point of this method. To reach a "normal forest", we need to have a a complete series of age classes that would allow an equal volume yields from annual or periodic cuttings under the given rotation and the silviculture system. In addition, the author emphasized the motivation to determine the maximum financial yield, as well as the relation between the size of the growing stock, its distribution among trees of different sizes and volume increase.

This study aimed to describe the dynamics of the diametric distribution and to propose a silviculture intervention using the Liocourt method for a natural forest of Brazilian pine (Araucaria angustifolia) located within 84 ha of Lages, Santa Catarina State forests, Southern Brazil. This research introduces the knowledge to promote a sustainable forest production in mixed ombrophilous forest areas, bringing environmental, financial and social benefits to forest owners and to Brazilian society.

\section{Results and Discussion}

\section{Comparison of the diameter distribution (2012-2016)}

The diameter distribution of this Brazilian pine fragment behaved as expected for unequal forests (Figure 1), presenting distribution curves in the J-inverted form (Alves Junior, 2010; Hess et al., 2010; Hess, 2012; Ricken, 2014). This distribution presents a balanced structure, which allows the determination of intervention based on the model for unequal forests proposed by De Liocourt (1989).

In the first evaluation (2012), 328 individuals were measured, and in 2016 this number increased to 330 , due to the higher in-growth rate than the mortality rate, representing three ingrowth and one mortality.

A decrease of $18.82 \%$ in the number of individuals was observed in the class center of $12.5 \mathrm{~cm}$, compared with the survey conducted in 2012 (Figure 2). This demonstrates that the forest ingrowth is low, a fact that may related with the competition by the individuals with minor diameters. The other diameter classes had an unimpressive increase of individuals, and the classes of $22.5 \mathrm{~cm}$ and $67.2 \mathrm{~cm}$ maintained the number of trees steady, indicating a stagnation of the growth caused by competition factors.

Only the class of $12.5 \mathrm{~cm}$ represented a significant ingrowth for the later diameter classes, when compared to the survey conducted in 2012. However, this reduction in the number of trees in the smallest diameter class compromises the dynamics of the future forest structure, indicating the need for silvicultural interventions to conserve the forest structure.

\section{Liocourt quotient " $q$ " - The diminution quotient}

The value of the Liocourt quotient " $q$ " for the studied population was 1.32, while in 2012 (first survey) the value found by Ricken was 1.4. Studies by Hess et al. (2010), Hess (2012) and Hess et al. (2014), using the Liocourt quotient as a proposal for the management of Brazilian pine in the Santa Catarina State, found " $\mathrm{q}$ " values of 1.33, 1.32 and 1.1, respectively. It is important to emphasize that Liocourt values resembling 1 indicate a higher concentration of individuals in the initial diameter classes and a low frequency of individuals in the larger diameters classes (Alves Junior et al., 2010).

In contrast with the survey in 2012, the lower value of "q" found in this study (2016) is due to the decrease in individuals in the first diameter class $(10$ to $14.9 \mathrm{~cm})$ because they grew and reach the larger classes (Figure 2).

\section{Management proposition based on the " $q$ " value of Liocourt model}

Considering the quotient " $\mathrm{q}$ " values of 1.32 and total basal area of $27.3 \mathrm{~m}^{2}$. ha ${ }^{-1}$ and basal area remaining for maximum DBH $(42.5 \mathrm{~cm})$ of $14.4 \mathrm{~m}^{2}$.ha ${ }^{-1}$, we made a proposal of silvicultural intervention which consisted of varying Liocourt quotient values $(q=1.1,1.3,1.5)$. Thus, we established nine scenarios, considering the maximum DBH of $42.5 \mathrm{~cm}$ and basal areas remaining of 10,12 and $14 \mathrm{~m}^{2}$.ha ${ }^{-1}$ (Figure 3).

As shown in Figure 3, the increase in the " $q$ " value has permanence in the number of individuals with smaller diameters per hectare and a decrease in the number of trees with larger diameters, a fact that also evidenced by Costa (2015). While the remaining basal area increased, there was an increase in the number of individuals of all classes.

In Table 1, it is possible to observe the expected frequency, the number of trees to be removed and the basal area to be removed per diameter class, for the simulation of the Liocourt quotient of 1.1 and varying the remaining basal area to 10,12 and $14 \mathrm{~m}^{2}$.ha ${ }^{-1}$.

As shown in Figure 3, it is noted that for a " $q$ " value of 1.1 and the remaining basal area of $10 \mathrm{~m}^{2} . \mathrm{ha}^{-1}$, the expected frequency for class centers ranged from 12.5 to $47.5 \mathrm{~cm}$, which is considerably below compared to the observed frequency. A high number of trees to be removed especially individuals with smaller diameters. 
Table 1. Diameter classes, observed and estimated frequencies, number of trees and basal area to be removed for a maximum diameter of $42.5 \mathrm{~cm}$, with the simulation of the "q" value of 1.1 and the remaining basal area ranging from 10,12 and $14 \mathrm{~m}^{2}$.ha ${ }^{-1} \mathrm{for}$ a forest fragment of Araucaria angustifolia located in Lages, Santa Catarina, Brazil.

\begin{tabular}{|c|c|c|c|c|c|c|c|c|c|c|}
\hline \multirow[b]{2}{*}{$\mathrm{DBH}(\mathrm{cm})$} & \multirow[b]{2}{*}{$\mathrm{FO}\left(\mathrm{ha}^{-1}\right)$} & \multicolumn{3}{|c|}{ "q" = $1.1 \mathrm{Gr}=10$} & \multicolumn{3}{|c|}{ " $\mathrm{q} "=1.1 \mathrm{Gr}=12$} & \multicolumn{3}{|c|}{$" q "=1.1 \mathrm{Gr}=14$} \\
\hline & & $\begin{array}{l}\text { FE } \\
\left(\mathrm{ha}^{-1}\right)\end{array}$ & NR & $\begin{array}{l}\mathrm{G} \\
\left(\mathrm{m}^{2} \cdot \mathrm{ha}^{-1}\right)\end{array}$ & $\mathrm{FE}\left(\mathrm{ha}^{-1}\right)$ & NR & $\begin{array}{l}\mathrm{G} \\
\left(\mathrm{m}^{2} \cdot \mathrm{ha}^{-1}\right)\end{array}$ & $\mathrm{FE}\left(\mathrm{ha}^{-1}\right)$ & NR & $\begin{array}{l}\mathrm{G} \\
\left(\mathrm{m}^{2} \cdot \mathrm{ha}^{-1}\right)\end{array}$ \\
\hline 12.5 & 69 & 32 & 37 & 0.454 & 38 & 31 & 0.243 & 44 & 25 & 0.307 \\
\hline 17.5 & 55 & 29 & 26 & 0.625 & 34 & 21 & 0.371 & 40 & 15 & 0.361 \\
\hline 22.5 & 35 & 26 & 9 & 0.358 & 31 & 4 & 0.126 & 37 & - & \\
\hline 27.5 & 33 & 24 & 9 & 0.535 & 28 & 5 & 0.245 & 33 & - & \\
\hline 32.5 & 29 & 22 & 7 & 0.581 & 26 & 3 & 0.212 & 30 & - & \\
\hline 37.5 & 24 & 20 & 4 & 0.442 & 24 & - & & 27 & - & \\
\hline 42.5 & 27 & 18 & 9 & 1.277 & 21 & 6 & 0.754 & 25 & 2 & 0.251 \\
\hline 47.5 & 29 & 16 & 13 & 2.303 & 19 & 10 & 1.590 & 23 & 6 & 0.954 \\
\hline 52.5 & 13 & 15 & - & & 18 & - & & 21 & - & \\
\hline 57.5 & 7 & 13 & - & & 16 & - & & 19 & - & \\
\hline 62.5 & 5 & 12 & - & & 15 & - & & 17 & - & \\
\hline 67.5 & 2 & 11 & - & & 13 & - & & 15 & - & \\
\hline 72.5 & 2 & 10 & - & & 12 & - & & 14 & - & \\
\hline Total & 330 & & 114 & 6.575 & & 80 & 3.541 & & 48 & 1.873 \\
\hline
\end{tabular}

Where: $\mathrm{DBH}=$ Diameter at the breast height , FO = Observed frequency; $\mathrm{FE}=$ estimated frequency; $\mathrm{NR}$ = number of trees to be removed per diameter class center $\mathrm{G}=$ basal area in square meters per hectare to be remove per diameter class center.

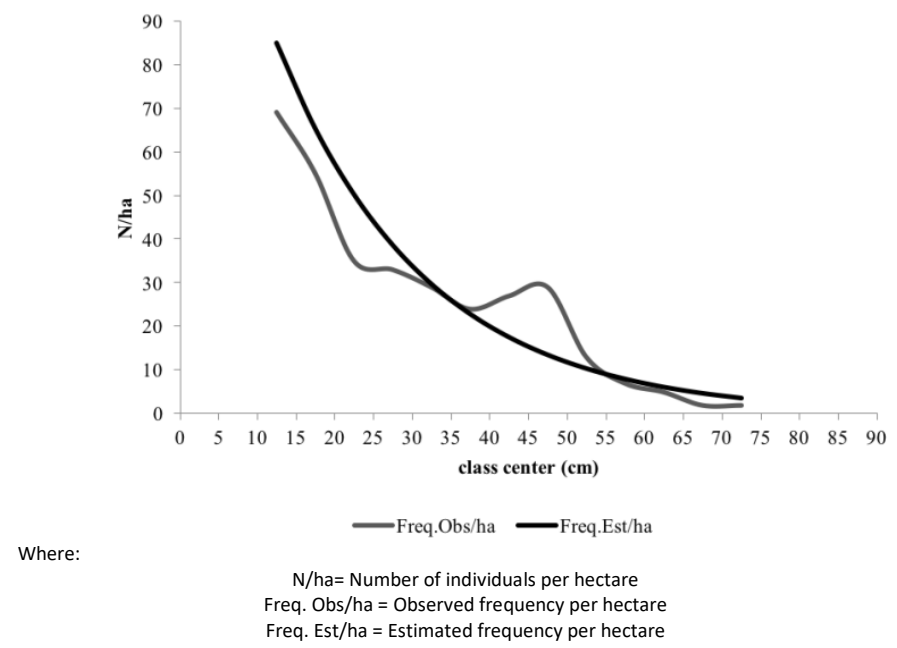

Fig 1. Estimated frequency and observed frequency for a maximum diameter of $42.5 \mathrm{~cm}$ in a forest fragment of Araucaria angustifolia located in Lages, Santa Catarina, Brazil.

Table 2. Diameter classes, observed and estimated frequencies, number of trees and basal area to be removed for a maximum diameter of $42.5 \mathrm{~cm}$, with the simulation of the "q" value of 1.3 and the remaining basal area ranging from 10,12 and $14 \mathrm{~m}^{2}$. ha ${ }^{-1} \mathrm{for}$ a forest fragment of Araucaria angustifolia located in Lages, Santa Catarina, Brazil.

\begin{tabular}{|c|c|c|c|c|c|c|c|c|c|c|}
\hline \multirow[b]{2}{*}{$\begin{array}{l}\text { DBH } \\
(\mathrm{cm})\end{array}$} & \multirow[b]{2}{*}{$\mathrm{FO}\left(\mathrm{ha}^{-1}\right)$} & \multicolumn{3}{|c|}{$" q "=1.3 \mathrm{Gr}=10$} & \multicolumn{3}{|c|}{$" q "=1.3 \mathrm{Gr}=12$} & \multicolumn{3}{|c|}{$" q "=1.3 \mathrm{Gr}=14$} \\
\hline & & $\begin{array}{l}\mathrm{FE} \\
\left(\mathrm{ha}^{-1}\right)\end{array}$ & $N R$ & $\begin{array}{l}\mathrm{G} \\
\left(\mathrm{m}^{2} \cdot \mathrm{ha}^{-1}\right)\end{array}$ & $\mathrm{FE}\left(\mathrm{ha}^{-1}\right)$ & NR & $\begin{array}{l}\text { G } \\
\left(\mathrm{m}^{2} \cdot \mathrm{ha}^{-1}\right)\end{array}$ & $\mathrm{FE}\left(\mathrm{ha}^{-1}\right)$ & NR & $\begin{array}{l}\mathrm{G} \\
\left(\mathrm{m}^{2} \cdot \mathrm{ha}^{-1}\right)\end{array}$ \\
\hline 12.5 & 69 & 59 & 10 & 0.122 & 71 & - & & 83 & - & \\
\hline 17.5 & 55 & 45 & 10 & 0.240 & 54 & 1 & 0.024 & 64 & - & \\
\hline 22.5 & 35 & 35 & - & & 42 & - & & 49 & - & \\
\hline 27.5 & 33 & 27 & 6 & 0.356 & 32 & 1 & 0.059 & 38 & - & \\
\hline 32.5 & 29 & 21 & 8 & 0.663 & 25 & 4 & 0.331 & 29 & - & \\
\hline 37.5 & 24 & 16 & 8 & 0.883 & 19 & 5 & 0.552 & 22 & 2 & 0.220 \\
\hline 42.5 & 27 & 12 & 15 & 2.128 & 15 & 12 & 1.702 & 17 & 10 & 1.418 \\
\hline 47.5 & 29 & 9 & 20 & 3.424 & 11 & 18 & 3.189 & 13 & 16 & 2.835 \\
\hline 52.5 & 13 & 7 & 6 & 1.299 & 9 & 4 & 0.866 & 10 & 3 & 0.649 \\
\hline 57.5 & 7 & 6 & 1 & 0.259 & 7 & - & & 8 & - & \\
\hline 62.5 & 5 & 4 & 1 & 0.306 & 5 & - & & 6 & - & \\
\hline 67.5 & 2 & 3 & - & & 4 & - & & 5 & - & \\
\hline 72.5 & 2 & 3 & - & & 3 & - & & 4 & - & \\
\hline Total & 330 & & 85 & 9.68 & & 45 & 6.723 & & 31 & 5.122 \\
\hline
\end{tabular}

Where: $\mathrm{DBH}=$ Diameter at the breast height , FO = Observed frequency; FE = estimated frequency; NR = number of trees to be removed per diameter class center $\mathrm{G}=$ basal area in square meters per hectare to be remove per diameter class center. 


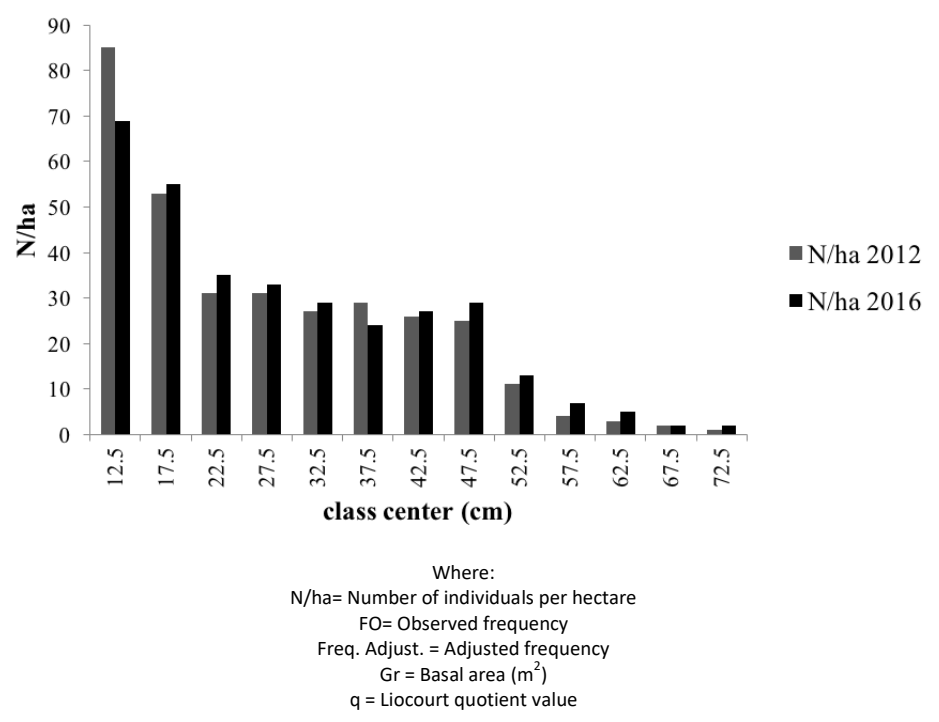

Fig 2. Distribution of the number of trees per diameter class center in 2012 measurements and remediation in 2016, in a forest fragment of Araucaria angustifolia located in Lages, Santa Catarina, Brazil.

Table 3. Diameter classes, observed and estimated frequencies, number of trees and basal area to be removed for a maximum diameter of $42.5 \mathrm{~cm}$, with the simulation of the "q" value of 1.5 and the remaining basal area ranging from 10,12 and $14 \mathrm{~m}^{2}$. ha ${ }^{-1} \mathrm{for}$ a forest fragment of Araucaria angustifolia located in Lages, Santa Catarina, Brazil.

\begin{tabular}{|c|c|c|c|c|c|c|c|c|c|c|}
\hline \multirow{2}{*}{$\begin{array}{l}\text { DBH } \\
(\mathrm{cm})\end{array}$} & \multirow{2}{*}{$\begin{array}{l}\text { FO } \\
\left(\mathrm{ha}^{-1}\right)\end{array}$} & \multicolumn{3}{|c|}{ "q" = $1.5 \mathrm{Gr}=10$} & \multicolumn{3}{|c|}{$" q "=1.5 \mathrm{Gr}=12$} & \multicolumn{2}{|c|}{ "q" = $1.5 \mathrm{Gr}=14$} & \multirow[b]{2}{*}{$\mathrm{G}\left(\mathrm{m}^{2} \cdot \mathrm{ha}^{-1}\right)$} \\
\hline & & $\mathrm{FE}\left(\mathrm{ha}^{-1}\right)$ & NR & $G\left(m^{2} \cdot h a^{-1}\right)$ & $\mathrm{FE}\left(\mathrm{ha}^{-1}\right)$ & NR & $\mathrm{G}\left(\mathrm{m}^{2} \cdot h \mathrm{~h}^{-1}\right)$ & $\mathrm{FE}\left(\mathrm{ha}^{-1}\right)$ & NR & \\
\hline 12.5 & 69 & 93 & - & & 112 & - & & 131 & - & \\
\hline 17.5 & 55 & 62 & - & & 75 & - & & 87 & - & \\
\hline 22.5 & 35 & 42 & - & & 50 & - & & 58 & - & \\
\hline 27.5 & 33 & 28 & 5 & 0.296 & 33 & - & & 39 & - & \\
\hline 32.5 & 29 & 18 & 11 & 0.912 & 22 & 7 & 0.580 & 26 & 3 & 0.248 \\
\hline 37.5 & 24 & 12 & 12 & 1.325 & 15 & 9 & 0.865 & 17 & 7 & 0.773 \\
\hline 42.5 & 27 & 8 & 19 & 2.695 & 10 & 17 & 2.411 & 11 & 16 & 2.269 \\
\hline 47.5 & 29 & 5 & 24 & 4.252 & 7 & 22 & 3.899 & 8 & 21 & 3.721 \\
\hline 52.5 & 13 & 4 & 9 & 1.948 & 4 & 9 & 1.948 & 5 & 8 & 1.731 \\
\hline 57.5 & 7 & 2 & 5 & 1.298 & 3 & 4 & 0.950 & 3 & 4 & 0.950 \\
\hline 62.5 & 5 & 2 & 3 & 0.920 & 2 & 3 & 0.920 & 2 & 3 & 0.920 \\
\hline 67.5 & 2 & 1 & 1 & 0.357 & 1 & 1 & 0.357 & 2 & - & \\
\hline 72.5 & 2 & 1 & 1 & 0.412 & 1 & 1 & 0.412 & 1 & 1 & 0.412 \\
\hline Total & 330 & & 90 & 14.415 & & 73 & 12.342 & & 63 & 11.024 \\
\hline
\end{tabular}

Where: $\mathrm{DBH}=$ Diameter at the breast height, $\mathrm{FO}=$ Observed frequency; $\mathrm{FE}=$ estimated frequency; $\mathrm{NR}=$ number of trees to be removed per diameter class center , $\mathrm{G}=$ basal area in square meters per hectare to be remove per diameter class center.

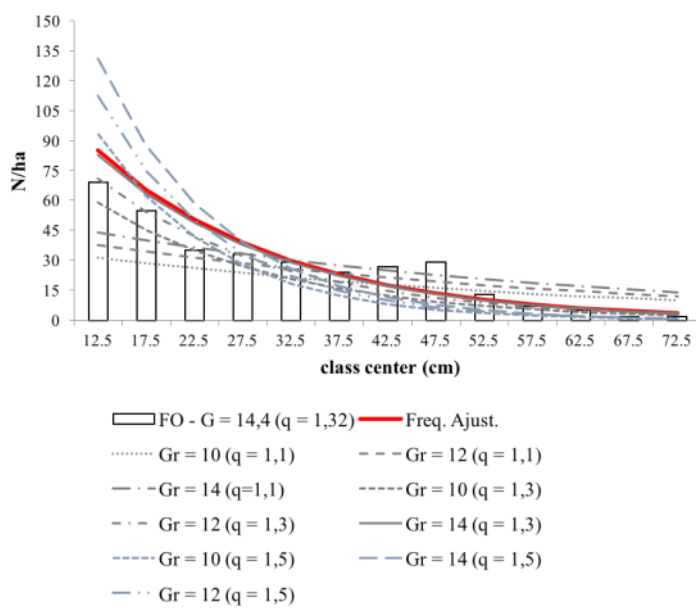

Where: $\mathrm{N} / \mathrm{ha}=$ Number of individuals per hectare

Fig 3. Distribution of observed frequency and adjusted frequency for Araucaria angustifolia forest in Lages, Santa Catarina, Brazil, aiming at silvicultural interventions as proposed by Liocourt method, and considering basal areas remaining of $10 ; 12$ and $14 \mathrm{~m}^{2}$. ha${ }^{1}$ with Liocourt's quotient values ranging from: $1.1 ; 1.3$ and 1.5 for a maximum DAP of $42.5 \mathrm{~cm}$. 
Table 4. Classes of diameter, observed and estimated frequencies, basal area, volume, number of trees and basal area to be removed for a maximum diameter of $42.5 \mathrm{~cm}$ and a value of "q" of 1.32 for a forest fragment of Araucaria angustifolia located in Lages, Santa Catarina, Brazil.

\begin{tabular}{|c|c|c|c|c|c|c|}
\hline $\begin{array}{l}\text { DBH } \\
(\mathrm{cm})\end{array}$ & $\begin{array}{l}\text { FO } \\
\left(\mathrm{ha}^{-1}\right)\end{array}$ & $\begin{array}{l}\mathrm{FE} \\
\left(\mathrm{ha}^{-1}\right)\end{array}$ & $\begin{array}{l}\mathrm{G} \\
\left(\mathrm{m}^{2} \cdot h \mathrm{~h}^{-1}\right)\end{array}$ & $\begin{array}{l}\text { V } \\
\left(\mathrm{m}^{3} \cdot \mathrm{ha}^{-1}\right)\end{array}$ & NR & $G\left(m^{2} h a^{-1}\right)$ \\
\hline 12.5 & 69 & 85 & 0.846 & 3.687 & - & \\
\hline 17.5 & 55 & 65 & 1.322 & 9.244 & - & \\
\hline 22.5 & 35 & 50 & 1.391 & 11.390 & - & \\
\hline 27.5 & 33 & 39 & 1.960 & 18.623 & - & \\
\hline 32.5 & 29 & 30 & 2.405 & 25.589 & - & \\
\hline 37.5 & 24 & 23 & 2.650 & 27.471 & 1 & 0.110 \\
\hline 42.5 & 27 & 18 & 3.830 & 43.681 & 9 & 1.269 \\
\hline 47.5 & 29 & 14 & 5.138 & 57.119 & 15 & 2.658 \\
\hline 52.5 & 13 & 10 & 2.814 & 33.958 & 3 & 0.649 \\
\hline 57.5 & 7 & 8 & 1.817 & 21.926 & - & \\
\hline 62.5 & 5 & 6 & 1.533 & 17.010 & - & \\
\hline 67.5 & 2 & 5 & 0.715 & 7.762 & - & \\
\hline 72.5 & 2 & 4 & 0.825 & 10.590 & - & \\
\hline Total & 330 & & 27.246 & 288.51 & 28 & 4.686 \\
\hline
\end{tabular}

Where: $\mathrm{DBH}=$ Diameter at the breast height , $\mathrm{FO}=$ Observed frequency; $\mathrm{FE}=$ estimated frequency; $\mathrm{NR}$ = number of trees to be removed per diameter class center $\mathrm{G}=$ basal area in square meters per hectare $\mathrm{V}=$ volume in cubic meters per hectare.

Table 5. Determination of the sustainable cutting rate for a natural fragment of Araucaria angustifolia in $1 \mathrm{ha}$.

\begin{tabular}{lllll}
\hline PAlv\% & $\begin{array}{l}\text { Cutting cycle } \\
\text { (years) }\end{array}$ & Cutting Intensity (\%) & $\begin{array}{l}\text { Commercial } \\
\text { without bark }\left(\mathrm{m}^{3}\right)\end{array}$ & $\begin{array}{l}\text { volume } \\
\left(\mathrm{m}^{3}\right)\end{array}$ \\
\hline 1.34 & 20 & 23.37 & & 44.89 \\
1.68 & 25 & 33.14 & 192.05 & 63.64 \\
2.016 & 30 & 45.05 & & 86.52 \\
\hline
\end{tabular}

Where: PAlv\%: Periodic annual increment in percentage of volume

With the increase in remaining basal area, there was a rise in the number of trees in all diametric classes combined with a decrease in the number of trees to be removed from the fragment and, consequently a decrease in the basal area to be harvested.

It is important to highlight that this tendency of increase in the number of trees in all diametric classes due to enhancement of the remaining basal area was also observed for the Liocourt quotient simulations of 1.3 (Table 2) and 1.5 (Table 3).

Considering the " $q$ " of 1.3 , the trees need to be removed to focus more on the diametric classes of 12.5 to $62.5 \mathrm{~cm}$ (Table 2). In comparison, " $q$ " of 1.1 presents a decrease of NR and an increase in the total basal area to be harvested, as a consequence of the larger diameters of the trees that would be removed. By simulation of " $q$ " 1.5, the NR is in the classes of 27.5 to $72.5 \mathrm{~cm}$ (Table 3), increasing the total basal area to be removed per hectare of the fragment.

Analyzing the simulation for the values of $1.1,1.3$ and 1.5 (Table 1, 2 and 3), we can state that the " $q$ " of 1.5 and the remaining basal area of 12 or $14 \mathrm{~m}^{2}$.ha ${ }^{-1}$ are the best scenarios for the Araucaria fragment, since the trees that need removal would be those of larger diameters, meaning that trees with small diameters would be maintained. This activity is important because it provides the stability of the fragment.

However, for forest characteristics with " $q$ " equal to 1.5 and a basal area remaining of 12 or $14 \mathrm{~m}^{2}$.ha ${ }^{-1}$, it would be necessary to insert some individuals in the classes 12.5 to $27.5 \mathrm{~cm}$ (Table 3). Therefore, for the remaining basal area of $12 \mathrm{~m}^{2}$.ha- $\mathrm{h}^{-1}$ it would be necessary to plant 78 Araucaria seedlings and for the remaining basal area of $14 \mathrm{~m}^{2}$.ha ${ }^{-1}$, the manager should plant 123 seedlings.

\section{Cutting intensity and cutting rate based on Liocourt quotient and forest increment}

The management by Liocourt method consists of the establishment of a maximum diameter. So for this study, we stipulated a maximum diameter of $42.5 \mathrm{~cm}$. In order to obtain the number of trees to be removed in each diameter class, the observed frequency was subtracted from the estimated frequency (Table 4). In addition, Table 4 shows the quantity of the basal area for the individuals that can be harvested in each class, as well as the commercial volume, considering the maximum diameter of $42.5 \mathrm{~cm}$.

According to the Table 4, Araucaria individuals from the diameter classes 37.5 to $52.5 \mathrm{~cm}$ can be removed for the desired maximum diameter of $42.5 \mathrm{~cm}$, representing 28 trees per hectare and a basal area of approximately 4.69 $\mathrm{m}^{2}$.ha ${ }^{-1}$. Considering the total area $(84 \mathrm{ha})$, the silvicultural intervention can remove $394 \mathrm{~m}^{2}$; thus, avoiding the increment stagnation of this fragment.

In this fragment, when the study considered only the classes above $40 \mathrm{~cm}$, the total volume was $288.51 \mathrm{~m}^{3}$. ha ${ }^{-1}$ and the commercial volume was $192.05 \mathrm{~m}^{3}$. ha ${ }^{-1}$. For the 84 hectares, the commercial volume was $16,132.2 \mathrm{~m}^{3}$. Based on the PAlv weighted $\%$, the Table 5 presents the sustained cutting rate for Brazilian pine stands/fragments considering cutting cycles of 20, 25 and 30 years.

The values of cutting intensity and cutting rate varied according to the value established for the cutting cycle (Table 5). Applying a cutting cycle of 20 years, the cutting intensity was $23.37 \%$ with a cutting rate of $44.89 \mathrm{~m}^{3}$.ha ${ }^{-1}$, while the cutting cycle of 25 years the cutting intensity was $33.14 \%$ and the cutting rate of $63.64 \mathrm{~m}^{3} \cdot \mathrm{ha}^{-1}$. When the 
cutting cycle was 30 years, the cutting intensity was $45.05 \%$ and the cutting rate was $86.52 \mathrm{~m}^{3} . \mathrm{ha}^{-1}$.

In total, it is noteworthy that with the use of sustainable forest management, the potential volume of wood that can be removed from this fragment would bring economic, social and ecological benefits to the whole society.

In the economic sphere, the management activity would be an extra income for the population of the area. Also, in the social concepts, the producers would see the benefits provided by forest and would protect and conserve it more effectively, recognizing its great potential and importance. In an ecological view, clearing a similar dimensions as natural has the potential to regulate the ecological conditions to active innumerable biological and biochemical processes, being these factors fundamental to generate forest dynamics, yield and growth in the managed areas (Ferreira et al., 2008)

\section{Materials and methods}

\section{Study area}

The study site is a natural fragment of Brazilian pine located in the municipality of Lages, Santa Catarina State, Brazil. It has a total area of 84 ha and it is located at the coordinates of $27^{\circ} 49^{\prime} 27$ "S and 50 $06^{\prime} 26^{\prime \prime} \mathrm{W}$. According to Köeppen classification, the climate is mesothermic humid ( $\mathrm{Cfb}$ ) with mild summers. The municipality has an approximate altitude of $987 \mathrm{~m}$, with average annual temperature variation between $13.8{ }^{\circ} \mathrm{C}$ and $15.8{ }^{\circ} \mathrm{C}$ and average annual rainfall ranging from $1360 \mathrm{~mm}$ to $1600 \mathrm{~mm}$ (Pandolfo et al., 2002).

\section{Data collection from plant materials}

In the year 2012, 25 plots (fixed area method) were installed systematically in the area. They have a dimension of $20 \mathrm{~m} \mathrm{x}$ $20 \mathrm{~m}$, totaling $400 \mathrm{~m}^{2}$ each one, being the distance between plots of $50 \mathrm{~m}$ and between lines of $100 \mathrm{~m}$. Biometric data were collected from all trees with diameter at breast height (DBH) from $10 \mathrm{~cm}$. In 2016, all trees were re-measured to obtain the DBH and total height (h) and also we verified the ingrowth and mortality.

\section{Data processing and analysis}

In order to calculate the Liocourt quotient " $q$ " to evaluate the diametric structure and to propose the sustainable management for this fragment, the individuals were divided into diametric classes with intervals of $5 \mathrm{~cm}$. Frequency data per diameter classes were adjusted using the Meyer distribution function (equation 1 ):

$\mathrm{Ni}=\mathrm{e}^{\beta 0+\beta 1 . D B H i}+\varepsilon i$

Where;

$\mathrm{Ni}=$ frequency per hectare in the class of diameter $\mathrm{i}$;

$\mathrm{DBHi}=$ center of DBH class, in centimeters;

$\beta 0$ and $\beta 1=$ estimated regression coefficients;

$\varepsilon i=$ residual error.

Afterwards, from the adjusted distribution function, the quotient " $q$ " was obtained, with the use of equation 2, which uses the ratio between the frequencies of a class of any diameter $(\mathrm{Xi})$, by the frequency immediately above $(\mathrm{Xi}+$ 1).

$\mathrm{q}=\frac{\mathrm{e}^{(\beta 0+\beta 1 . \mathrm{DBHi})}}{\mathrm{e}^{(\beta 0+\beta 1 . \mathrm{DBHi}+1)}}$

Where:

$q=$ Liocourt quotient value;

$\mathrm{DBHi}=$ center of DBH class, in centimeters;

$\beta 0$ and $\beta 1$ = estimated regression coefficients;

\section{Intensity and proposition of intervention for three cutting cycles}

For the volume calculation we used the equation proposed by Hess et al. (2007), with $R^{2} a j$. of 0.99 , standard error of $0.0254 \mathrm{~m}^{3}$, coefficient of variation of $4.16 \%$ and $F$ value of 26277.8 (equation 3 ):

$v=0,0071+0,00005 * d b h^{2}+0,00003 * d b h^{2 *} h+0,00004 * d b h^{*} h^{2}-0,0006 * h^{2}$

(3)

Where:

$\mathrm{V}=$ volume in cubic meters;

$\mathrm{DBH}=$ diameter at the breast height in centimeters;

$\mathrm{H}=$ total height in meters.

The periodic annual increment in percentage of volume (PAlv\%) for the area is $1.68 \%$ for a cutting cycle of 25 years, according to Ricken (2014). Considering this cutting cycle, the cutting intensity (equation 4) and the cutting rate (equation 5) were determined.

$\mathrm{IC}=\left[1-\left(\frac{1}{1,0 \mathrm{icc}}\right)\right] * 100$

Where:

$\mathrm{Cl}$ : Cutting intensity, in percentage of volume;

I: Periodic Annual increment in percentage of volume;

Cc: Cutting cycle in years.

$\mathrm{TC}=\mathrm{Vr} * \frac{\mathrm{IC}}{100}$

Where:

CR: Cutting rate in volume for the cutting cycle;

Vr: Actual forest volume available, in cubic meters;

$\mathrm{Cl}$ : Cutting intensity.

This study considered cutting cycles of 20, 25 and 30 years. It was based on studies performed in the same area by Hess (2010), where it obtained a cutting cycle of 23 years and by Ricken (2014), which established a cut cycle of 25 years.

\section{Conclusion}

The reduction in the number of individuals in the class of smaller diameter was observed in 2016 measurements and their insertion into the larger diameter classes was responsible for the decrease in the value of " $q$ ", which went down from 1.4 to 1.32. The Liocourt method as a forest management technique indicated the possibility of forest interventions with harvests ranging from $44.89 \mathrm{~m}^{3}$.ha ${ }^{-1}$ to $86.52 \mathrm{~m}^{3}$.ha ${ }^{-1}$, in cutting cycles ranging from 20 to 30 years. Finally, the sustainable forest management of this population, which aims to remove the individuals with larger diameters, will provide more space for the remaining trees, 
improving its development, since it would reduce the competition for space, light, and nutrients.

\section{Acknowledgments}

The authors are thankful for the support of the Santa Catarina State University, Department of Forest Engineering and its Graduate Program, the FUMDES - Support Fund for the Maintenance and Development of Higher Education for the financial assistance for this research, the FAPESC - Santa Catarina State Foundation for Support of Research and Innovation for the support to infrastructure for Research Group, Process N 2017TR639 and the owners of the Brazilian Pine Forest for the availability of this study.

\section{References}

Alves Júnior F T, Ferreira R L C, Silva J A A, Marangon L C, Costa Júnior R F, Silva S O (2010) Utilização do quociente de de Liocourt na avaliação da distribuição diamétrica em fragmentos de Floresta Ombrófila Aberta em Pernambuco. Cienc Florest. 20 (2): 307-319.

Batista A P B, Aparicío W C S, Aparício P S, Santo V S, Lima R B, Mello J M (2015) Caracterização estrutural em uma floresta de terra firme no estado do Amapá, Brasil. Pesqui Florest Brasil. 35 (81): 21-33.

Carvalho P E R (2003) Espécies florestais brasileiras. Brasília: Embrapa Informação Tecnológica; Colombo-PR: Embrapa Florestas, 1039.

Costa E A (2015) Modelagem biométrica de árvores com crescimento livre e sob competição em floresta de araucária. Thesis (Doctorate in Forest Engineering), Universidade Federal de Santa Maria, Santa Maria. 1-235.

De Liocourt $F$ (1898) De l'amenagement des sapinières. Bull Soc For Franche-ComtéBelfort. 6: 396-409.

Ferreira W C, Ferreira M J, Martins J C (2008) Regeneração natural de espécies arbustivo-arbóreas no sub-bosque de Eucalyptus grandis em Mata Ciliar, no município de Lavras, MG. R Bras Bioci. 5 (1): 579-581.

Guerra M P, Silveira V, Reis M S, Schneider L (2002) Exploração, manejo e conservação da araucária (Araucaria angustifolia). In: Simões, L L and Lino, C F (ed) Sustentável Mata Atlântica: A exploração de seus recursos florestais. Senac, São Paulo, 85-102.

Hess A F, Schneider P R, Andrade C M (2007) Crescimento em volume de Araucaria angustifolia (Bertol.) Kuntze na serra do sudeste do estado do Rio Grande do Sul. Cienc Florest. 17 (3): 247-256.
Hess A F, Calgarotto A R, Pinheiro R, Wanginiak T C R (2010) Proposta de manejo de Araucaria angustifolia utilizando o quociente de Liocourt e análise de incremento, em propriedade rural no município de Lages, SC. Pesqui Florest Brasil. 30 (64): 337-345.

Hess A F (2012) Manejo de Araucaria angustifolia pelo quociente de liocourt em propriedade rural no Município de Painel, SC. Pesqui Florest Brasil. 32 (70): 227-232.

Hess A F, Minatti M, Ferrari L, Pintro B A (2014) Manejo de floresta ombrófila mista pelo método de liocourt, município de Painel, SC. Cerne. 20 (4): 575-580.

Kerr G (2014) The management of silver fir forests: de Liocourt (1898) revisited. Forestry. 87 (1): 29-38.

Lorenzi H (2002) Árvores brasileiras: manual de identificação e cultivo de plantas arbóreas nativas do Brasil, 4 ed. Instituto Plantarum, Nova Odessa. 368.

Medeiros J D, Savi M, Brito B F A (2005) Seleção de áreas para criação de Unidades de Conservação na Floresta Ombrófila Mista. Biotemas. 18 (2): 33-50.

Meyer H A (1933) Eine mathematisch-statisch Untersuchung uber den Aufbau dês Plentterwaldes, Scuweiz. Ztschr. f. Forstw. 84

Pageo F M, Arrarás I R (2013) The application of the Liocourt model to uneven-aged cork oak stands. Ital J For Mt Environ. 68 (2): 85-93.

Pandolfo C, Braga H J, Silva Jr V P, Massignam A M, Pereira E S, Thomé V M R, Valci F V (2002) Atlas climatológico do Estado de Santa Catarina. Epagri, Florianópolis. CD-Rom

Paula J E, Alves J L H (2007) 897 madeiras nativas do Brasil: anatomia -dendrologia - dendrometria - produção - uso, 1ed. Cinco Continentes, Porto Alegre. 438.

Picard N, Gasparotto D (2016) Liocourt's law for tree diameter distribution in forest stands. Ann Forest Sci. 73 (3): 751-755.

Ricken P (2014) Incremento, espaço horizontal e competição em povoamento natural de Araucaria angustifolia no planalto catarinense. Dissertation (Master in Forest Engineering), Universidade do Estado Santa Catarina, Lages. 1-105.

Rosot M A D (2007) Manejo florestal de uso múltiplo: uma alternativa contra a extinção da Floresta com Araucária? Pesqui Florest Brasil. 55: 75-85.

Sanquetta C R, Dalla Corte A P, Eisfeld R L (2003) Crescimento, mortalidade e recrutamento em duas florestas de Araucária (Araucaria angustifolia (Bert.) 0. Ktze.) no estado do Paraná, Brasil. Recen. 5 (1): 101-112. 